\title{
CASIMIR DAVAINE (1812-1882): A PRECURSOR OF PASTEUR
}

\author{
by
}

\section{JEAN THÉODORIDÈS*}

Several centuries before Pasteur's epoch-making discoveries, physicians and naturalists had suspected that certain contagious diseases in man and in domestic animals were caused by parasites invisible to the naked eye (this was named the 'contagium vivum' theory). ${ }^{1}$

Those views, at first purely theoretical, were confirmed in 1687 when two pupils of Francesco Redi: Bonomo and Cestoni proved that human scabies was caused by a tiny parasitic mite (nowadays known as Sarcoptes scabiei) which they were able to isolate and describe, thanks to the recently invented microscope.

A century and a half later, in 1835, Agostino Bassi (1773-1856), another Italian scientist, proved that another disease, silk-worm rot, is caused by a fungous parasite, which was named after him, Beauveria bassiana. ${ }^{2}$ In 1836-7, Alfred Donné isolated and described Trichomonas vaginalis, the vaginal Flagellate found in women $;^{3}$ and, between 1841 and 1844, David Gruby (1810-1898) isolated the fungi responsible for the most common human mycoses. He also discovered and described, in 1843-44, a new protozoon which he called 'trypanosome' in the frog."

Thus, up till this time, only protozoa and multicellular organisms such as one acarian and fungi, were recognized as playing a pathogenic role.

From 1676 on, certain bacteria had been observed and described by the well-known Dutch microscopist Anthony van Leeuwenhoek (1632-1723) but he was concerned only with non-pathogenic species which he found in vegetable or animal infusions or in dental tartar. Other free living bacteria were described during the eighteenth and nineteenth centuries.

The credit of demonstrating for the first time the pathogenic role of a bacterium in the human being and in domestic animals goes to the little-known French physician Casimir Davaine (1812-1882), whose bacteriological work is the main topic of this paper.

First of all, a few words on the man. The sixth of the nine children of a distiller at St. Amand-les-Eaux, in the North of France, Casimir-Joseph Davaine was born on 19 March, 1812. He began his studies at St. Amand, continued at Tournai and Lille, and in 1830 he registered at the Faculty of Medicine of Paris.

* This is the text of a lecture given on 10 May 1965 at the Wellcome Historical Medical Library, London. It constitutes an abridged version of a lecture given in Paris in 1963 and published under the title 'Casimir Davaine et les débuts de la Bactériologie médicale', Confs Palais Découv., 1964, No. 95. pp. 32. The author wishes to thank Miss J. Lawson, Dr. J. Schiller, and Dr. F. N. L. Poynter, who have helped him in his translation.

${ }^{1}$ Belloni, L., 'Le "contagium vivum" avant Pasteur', Confs Palais Découv., 1961, No. 74, pp. 35, illus.

' HARANT, H., and ThÉodoridès, J., 'Un pionnier de la Parasitologie et un précurseur des doctrines pastoriennes: Agostino Bassi '(1773-1856)' Montpell. méd., 1956, 50, 393-399.

3 THEODORIDĖs, J., 'Quelques parasitologistes microscopistes français du XIX' siecle', C. r. 85 $^{\circ}$ Congr. Socs sav. (Chambéry-Annecy 1960), 623-632.

'ThÉodoridè, J., 'L'oeuvre scientifique du Docteur Gruby', Revue Hist. Méd. hébr., 1954, 20, 27-36, 22, 138-143. 


\section{Jean Théodoridès}

In 1835 he became the 'externe' of Rayer at the Hôpital de la Charité where he met the celebrated Claude Bernard whose colleague, friend and physician he became. In 1837 he obtained his medical degree and started practising medicine to earn a living, while giving every spare moment to important research in the field of natural history and of pathology.

In 1848 he figures among the founding members of the all-important 'Société de Biologie' to which he contributed numerous papers.

This industrious man was both humble and modest; he never looked for honours and the only ones he received were the Cross of the Légion d'Honneur in 1858 and a seat in the Académie de Médecine in 1868.

Under the Second Empire, at the instigation of Rayer, Davaine was appointed 'médecin par quartier' of the Emperor without becoming a mere servile official.

Beside his medical practice, scientific research was his main occupation and, when we consider that he had no real laboratory, we cannot but be amazed at the work accomplished by this lonely research worker. He carried out his experiments in Rayer's department at La Charité, while keeping his animals at a friend's private house (A. d'Eichthal). He was one of the best-known practitioners of his time and his patients came from the most varied social environment. Among them were Alphonsine Plessis, otherwise known as Marie Duplessis, the immortal 'Dame aux camélias'; his illustrious friend, Claude Bernard, already mentioned; Davaine's teacher, Rayer, and the financial aristocracy of the Second Empire, the Rothschilds and d'Eichthals.

Davaine's philosophy of life is nowhere better expressed than in his little book 'Les éléments du bonheur' ('The elements of Happiness') published in 1871, during the Franco-Prussian War, when Davaine was a field doctor. Even all the alarms of war could not destroy his inner serenity and his belief in humanity. He spent the last years of his life on his property at Garches near Paris, now the Davaine Foundation. Here, after the 1870 war, he laid out a garden where, great nature-lover as he was, he cultivated hundreds of different varieties of his beloved roses. There he died on the 14 October, 1882, in his 71st year. He was gentle, distinguished, kind and modest; however if his scientific opinions were attacked, he knew how to defend himself and he became a fervent and formidable polemist, treating his adversary with contempt and knowing when to employ biting irony such as was the case in his controversy on septicaemia with Colin.

His monumental scientific work covers several biological fields: bacteriology, parasitology, plant pathology, zoology, general biology, and teratology. As I am at present finishing a book on Davaine, I shall confine myself here to his work on medical and veterinary bacteriology, a discipline in which, to quote Jean Rostand (Hommes de Vérité, II, Paris, 1948, p.56): 'he ranked not only as precursor but as a founder'. Rostand also said: 'Davaine will be remembered by men for his wonderful research which he started in 1850 on the causes of anthrax' (Ibid, p. 43).

By the term 'Anthrax' several different diseases are designated which are transmissible from animal to man. At the end of the eighteenth century Chabert had already distinguished three principal kinds: 'anthrax fever', 'essential anthrax' and 'symptomatic anthrax'. 


\section{Casimir Davaine: A Precursor of Pasteur}

The first form is due to a microbe called Bacteridium anthracis, while the two others, also called bacterial anthrax (the Rauschbrand of German authors, or septic gangrene) have for agent another germ: Clostridium feseri (Feser 1876) (Bacterium chauvoei).

We shall only consider here the anthrax caused by bacteridium. This disease found in horses, cattle and sheep, which used to be known as 'Spleen blood' is accompanied by digestive troubles, intestinal haemorrhage, and haematuria. Several days later, the animal dies of asphyxia. In the human who has become infected through handling the skin or the meat of an animal suffering from anthrax, the disease begins with a cutaneous lesion (malignant pustule) on the uncovered parts of the body (face, neck, arm, leg, etc.) followed by gastro-intestinal symptoms (vomiting and diarrhoea). The gravity of infection varies and can be more or less serious according to the race or to the country where it is found, but on the whole it can be said that human beings are fairly resistant to anthrax. However, death can occur, being usually preceded by convulsions of a tetanic or epileptic nature.

A disease known since antiquity, anthrax still caused considerable losses among cattle in the nineteenth century. The so-called 'Siberian Plague' is nothing else than anthrax, which, between 1864 and 1866, caused the death of innumerable men and cattle. In the province of Novgorod alone 50,000 head of cattle and more than 500 human beings perished from anthrax between 1867 and 1870. Davaine ${ }^{5}$ quotes for the same year 1870 annual losses of 3 million francs for the Beauce region alone. At the end of the eighteenth century, the disease had been isolated from other epizootic conditions through the work of Fournier, Chabert, Enaux and Chaussier, but its range remained unknown. Pastures reputed to be dangerous to cattle were called 'Evil Grounds', and anthrax was still thought to be caused by miasmas originating from the ground, from irrigation water, or determined by meteorological factors. Other writers decided that bad fodder or dirty stables and sheepfolds were responsible for the disease. Again others, influenced by Broussais, said that anthrax signifies 'too much blood circulating in the arteries' with too high a percentage of red blood corpuscles. It is curious to note that the veterinary surgeon, Henri Delafond (1805-1861) who, in 1860, was to offer such an important contribution to the bacterial aetiology of anthrax, in his early works upheld the 'plethoric' theory to explain the disease.

However, it was already known that anthrax was contagious, virulent, and inoculable: in 1823, Barthélémy a professor at Alfort had shown that the disease was contagious by inoculating healthy animals with the blood of those infected with anthrax.

About the same time (1824) another Frenchman, Bernard Gaspard (1788-1871) published the results of his research undertaken since 1808; he injected various animals with pus or with decomposing organic matter and noticed the various symptoms and the lesions of the digestive mucous membrane. Gaspard also showed that the blood of a dog suffering from a 'putrid intoxication' could cause the same symptoms in another dog. Magendie, repeating these experiments, showed that the putrid blood has no effect on the digestive system, that its toxicity diminishes when filtered and also that the exhalation of the putrid substance has no effect on the

- Davanne, C., 'Études sur la contagion du charbon chez les animaux domestiques', Bull. Acad. Méd., 1870, 35, 215-235. 
animals. This was a convincing argument against 'miasmas' still generally incriminated in pathology.

The above experiments were put alongside those carried out with anthracic blood and it was prematurely concluded that the latter also was a blood infection of a 'putrid nature'. Raimbert in 1859 made the same mistake in his Traité des maladies charbonneuses and it will be seen later on that one of the obstacles Davaine encountered in his research on anthrax was the existence of another 'putrid' disease in cattle: septicaemia.

Davaine undertook his research on anthrax at the instigation of Rayer, that great pioneer of comparative pathology who counted among his pupils such great names as Claude Bernard, Davaine, Charcot and Charles Robin. L'Association médicale et vétérinaire d'Eure-et-Loire, an area particularly affected by anthrax, had encouraged investigation of the disease, an investigation in which both Davaine and Rayer participated. In June and July 1850 , the two scientists went to the Beauce region, not far from Chartres and the following month Rayer read a paper at the recently founded Société de Biologie on the results obtained by inoculating anthracic blood into healthy sheep. ${ }^{6}$

Rayer wrote the following about the blood of a sheep which died of anthrax:

Examined under the microscope, the blood was identical to that of a sheep infected by "spleenblood" which had been used for inoculation. The globules, instead of remaining individualized as in a healthy animal were packed together irregularly

and he added the following important sentence: ' . . . there were also small filiform bodies in the blood, about twice as long as a blood corpuscle'.

I. Straus, a pupil of Pasteur, wrote later:7

This is the first document which notes the anthrax bacteridium which afterwards became so famous.

It should be emphasized, however, that in the above-mentioned quotation Rayer does not connect the presence of these 'small filiform bodies' with the fact that the animal died of anthrax.

Five years later (1855), a German physician, Aloys Pollender (1800-1879), published a paper on anthracic blood and the treatment of the disease. He examined the blood under the microscope and detected the presence of stick-shaped corpuscles (stabförmige Körperchen) which he described in detail and even gave their size. He provided a very important detail when he said: "As to their shape, they are very much like the vibrio bacillus or the vibrio ambiguus'. By their chemical reactions he assumed that they belonged to the vegetable kingdom and he even hinted they were bacteria.

Further progress on Rayer's observation was made by Pollender who suggested that these corpuscles might be the real agent of the disease: 'Are they the actual infectious matter or are they simply carriers of this matter or have they no role whatever?' He added cautiously: 'Those questions cannot be answered'. Pollender claimed his first observations were made in 1849 , that is to say a year prior to Rayer. However the publication date of his work is five years later than Rayer's.

- Rayer, P., 'Inoculation du sang de rate', C. r. Séanc. Soc. Biol., 1850, 11, 141-144 (cf. p. 142).

'Straus, I., Le charbon des animaux et de l'homme, Paris, 1887, p. 25. 


\section{Casimir Davaine: A Precursor of Pasteur}

In 1857-58, another German scientist, Brauell, also noticed the stick-shaped corpuscles already seen by Rayer and Pollender. In observing some three-days-old anthracic blood under the microscope, it seemed to him that the corpuscles which were at first motionless later acquired 'active movements'. Brauell had in fact mistaken the bacteridia for the vibrios, which develop later when the putrefaction of the blood sets in. As one of Pasteur's famous pupils, Duclaux, properly said : ${ }^{8}$

Science is like a shunting engine; after advancing it sometimes retreats. Hardly had Pollender raised the question when Brauell confused the issue by mixing up the anthrax bacteridia with the common putrefaction bacteria.

In another experiment, Brauell claimed to have caused death by inoculating the blood of an anthracic horse into another animal, although there were no stick-shaped corpuscles present, and he wrongly concluded that they were neither the contagium itself nor its carriers. By confusing them with the putrefaction vibrios, he perpetuated the error.

In 1860, Delafond, already mentioned, took up the study of anthrax, and he also found the 'stick-shaped corpuscles' already seen by Rayer, Pollender and Brauell. In addition, Delafond pointed out Brauell's mistake in confusing the 'stick-shaped corpuscles' with the vibrios. He attempted to culture the bacteridia in small containers in order to obtain their full growth up to the point of giving spores or 'seeds'. Although Delafond was unable to observe these stages, his idea of trying to obtain them from the bacteridia was that of a real precursor, especially when we think that it was not until Robert Koch's classic paper (1876) that we had a description of the complete cycle of the bacteridium.

But let us go back to Davaine. From 1863 on, he attacked the problem of anthrax with tenacity and perseverance, trying to prove irrefutably that it was the bacteridium only which was the cause of the disease. In his first paper of $1863,{ }^{9}$ he comes back to his 1850 observation with Rayer and says,

I thought at that time that I should be able, when the occasion arose, to check on the existence of those filiform infusorial bodies found in the blood of sheep which have died from anthrax and to find out if the development of these microscopic beings (rather like algae) was not the cause of deterioration in the blood and afterwards of the death of the animal.

The occasion had not arisen and other work had prevented me from continuing active research when, in February 1861, M. Pasteur published his remarkable work on the butyric ferment, a ferment consisting of small cylindrical rods which possess all the characteristics of vibrios and bacteria. The filiform corpuscles that $I$ had seen in the blood of anthracic sheep were much like the vibrios in shape and I was led to try and discover if this kind of corpuscle (or others of the same nature as those which determine butyric fermentation) when introduced in the blood of the animal would not act as a ferment.

He inoculated two rabbits and a white rat with the blood of a sheep which had died from anthrax and noticed that the animals died after 43 and 63 hours respectively, while a third rabbit inoculated with the blood of the one which died first, died after 17 hours. He also gave a good description of the bacteridium and had a hint of its infectious role:

- Duclaux, E., Pasteur, Histoire d'un esprit, Paris, 1896, p. 292.

- Davaine, C., "Recherches sur les infusoires du sang dans la maladie connue sous le nom de sang de rate', C. r. Acad. Sci., 1863, 57, 220, 351, 386. 


\section{Jean Théodoridès}

The "spleen-blood" bacteria are free, straight, inflexible and cylindrical filaments varying between 4 and 12/1000 of a millimeter in length, extremely thin; the longest sometimes have one or very rarely two inflexions at an obtuse angle; with high magnification, it is possible to distinguish traces of a division into segments; they have no spontaneous movement at all. When dried up they keep their shape and appearance. Sulphuric acid and potassium in concentrate solution do not destroy them.

\section{As Straus appropriately said:}

The importance of this observation is less in the facts themselves already established by Brauell and Delafond, but, as we have seen, in the interpretation of these facts; enlightened by the recent discoveries of $\mathbf{M}$. Pasteur, Davaine takes a bold stand and going further than his predecessors, he foresees the aetiological role of the anthracic filaments.

Still in the same year, 1863, Davaine brought forward a whole series of very important facts:

1. Anthracic blood is not infectious as long as the 'stick-shaped corpuscles' have not appeared.

2. He proposed the term 'bacteridia' still in use today to designate these 'stick-shaped corpuscles'.

3. He believed that in pregnant females, the placenta acts like a filter retaining the bacteridia and thus protecting the foetus from the disease.

4. He noticed that putrefied anthracic blood caused in the inoculated animals a different disease, and in so doing he was already distinguishing septicaemia from anthrax.

5. He proved that dried anthracic blood will remain virulent a long time; blood kept dry for eleven months, then moistened and inoculated, still transmits the disease.

6. He established that birds and frogs seem to be refractory to anthrax.

7. Finally, he noticed that the term 'spleen-blood' applied to anthrax is improper, since all the blood and not only the spleen blood is infested by bacteridia.

In 1864, Davaine studied the 'malignant pustule' which is the localised human form of anthrax and proved by microscopic examination that the bacteridia found in it are the same as those in the blood of anthracic animals. Thus he confirmed the clinical findings of Fournier (1789) who had already shown that anthrax can be transmitted from animal to man. After these results, one would have supposed that the question of anthrax was finally settled, the infectious role of the bacteridium having been clearly proved. But as Jean Rostand has written:

In order to understand the way of thinking of Davaine's contemporaries around 1860, we must try to set ourselves back at the time when the word 'microbe' did not exist-the term was to be coined by Sédillot in 1878 -and when the idea, so familiar to us today, of connecting the outbreak of a disease with the activity of a microscopic organism went against the opinions of the greatest authorities. (op. cit. p. 56-57).

Criticism of Davaine's opinions was made by physicians and veterinarians against whom he had to combat vigorously in the way Pasteur was to do later. Davaine's main opponents were Emile-Claude Leplat (1826-1906) and Pierre-François Jaillard (1827-1883), professors at the Val-de-Grâce Hospital, both of whom published several papers against him. In a first paper (1864) they tried to prove that animals inoculated with any given bacteria obtained from vegetable infusions or from putrefied animal matter either do not die, or else die with dysenteric or convulsive manifestations different from those caused by anthrax. They did not use anthracic blood in their experiments. They concluded from this unusual kind of experiment that bacteria have no deleterious effect. Briefly stated, according to Leplat and Jaillard, 


\section{Casimir Davaine: A Precursor of Pasteur}

there was no difference between common bacteria and the anthrax bacteridia. Davaine refuted vigorously such assertions. The two opponents did not lay down arms. They claimed that the inoculations of blood from an anthracic cow into two rabbits, although causing their death, this occurred in the absence of bacteria which could not be detected in the blood. Consequently, their conclusion was that anthrax is not of a parasitic nature and the bacteria, when found, merely represented a side phenomenon. They went as far as to say that the less bacteria present in the blood, the more virulent it was. Davaine replied to these objections by several papers, presented to the Académie des Sciences in 1865, Pasteur and Claude Bernard being present. After an anatomo-pathological examination of the rabbit inoculated by Leplat and Jaillard, Davaine concluded that it was not anthracic and that its blood inoculated into other animals had not communicated anthrax to them. It was in fact an entirely different disease, bovine septicaemia, the symptoms of which he had clearly differentiated from those of anthrax and to the study of which he returned in detail, as we shall presently see.

As Claude Bernard said:

Jaillard and Leplat should have been very happy to discover a second disease, but not at allthey were happier to prove that Davaine was wrong.

In 1865, Davaine was awarded the Prix Bréant by the Académie des Sciences for his work on anthrax. The conclusions of the reporters were:

Either the bacteridium is the transmitting agent of anthrax or else it is the corpuscle which invariably accompanies the necessary condition for inoculation and development of the disease.

The doubt expressed in this sentence remained even after Koch's paper, and as Duclaux explains it in the following lines:

For the time being, the main question facing him [Pasteur] seemed to be: is the bacteridium the causal agent of anthrax or is it a companion-virus?

Seen from this point of view, the results of Davaine and even those of Koch still left room for hesitation and doubt.

In $1868^{10}$, Davaine in a general review on anthrax restated his deep conviction that the bacteridia alone are the agent of the disease. In his attempt to prove this once and for all, he performed two sets of new experiments. In the first, he emphasized the importance of separating the bacteridia from the rest of the blood by using filtration. But at this time, there existed no filters fine enough, and so he used a placenta, having seen in 1863 the role it played as a biological filter. A female guinea-pig was inoculated with anthracic blood during the period of gestation. It died two days later, and both blood and placenta were infested with multitude of bacteria while the foetus was completely free. In fact, this fine experiment is not conclusive because, as we know today, the placenta is not an obstacle to bacteridia.

The second set of experiments was much more valid. Having observed a bacterial disease in certain plants, Davaine noticed that if the bacteria were heated to a tem-

${ }^{10}$ Davaine, C., 'Sur la nature des maladies charbonneuses', Arch. gén. Méd., 1868, p. 144. 


\section{Jean Théodoridès}

perature of $52^{\circ} \mathrm{C}$. they became motionless and the disease was no longer transmitted.11 His conclusion reads as follows:

These experiments prove that a living being, endowed as it is with a very complex organisation, can be invaded and destroyed by a vibrio. In this fact will be seen, I hope, another argument in favour of the opinion I sustain on the nature of anthracic disease.

This paper is very important indeed in the history of medicine. It is one of the first publications in which the contagium vivum theory was proved experimentally and where the pathogenic agent, properly identified, is not a multicellular organism as it is in scabies or in mycoses. It is definitely a unicellular being, a bacterium, a microbe.

In 1868 Davaine tried to determine exactly the incubation period of anthrax as well as the quantity of bacteridia necessary to induce the disease. For this purpose he improved the technique of experimental inoculations by using the Pravaz syringe.12 Up to that time the laboratory animals had been inoculated by making little wounds with lancets, a procedure which caused numerous difficulties, such as a back flow of the inoculate, the risk of infection, and above all the impossibility of knowing the exact amount of the inoculate. With the syringe these difficulties were overcome. Davaine inoculated guinea-pigs quantitatively by this technique with anthracic blood diluted to concentrations varying between one hundredth and one thousandth of a drop. Death followed within 26 to 53 hours. The same symptoms were observed in all the guinea-pigs, only the time of incubation of the disease varied with concentration and Davaine drew the following conclusion:

This correlation between the quantity of the inoculated virus and the time of incubation is not mere accident, a chance effect, it is certainly the expression of a law the confirmation of which we shall see in another series of experiments.

Davaine concluded from all this that the quantity of bacteridia introduced into the animal economy is the main factor determining the length of the incubation period of anthrax. Thus, to the qualitative factor he added the essential quantitative one.

In 1869 Davaine performed a simple and elegant experiment to demonstrate that it is without doubt the bacteridium which is the pathogenic agent of anthrax: $\mathrm{He}$ diluted some anthracic blood in distilled water and after 24 hours the bacteridia fell to the bottom of the container. He then injected in one group of guinea-pigs a drop taken from the clear surface of the liquid and into another group a drop taken from the bottom. In the first case the guinea-pigs kept alive while in the second they died.

Before making a brief summary of Davaine's work on bovine septicaemia, it is important to recall his efforts to elucidate the means of transmission of anthrax and his therapeutic attempts. He began by discarding any explanations suggested by the action of external factors: fodder, nature of soil, climate, etc. ..., and he hypothesized that during an epidemic, flies may be the vectors of the disease. ${ }^{13}$ In this

\footnotetext{
11 It is interesting to note that in 1866 in his Études sur le vin, Pasteur advised heating, which destroyed the micro-organisms adulterating this liquid.

12 Davaine, C., 'Expériences relatives à la durée de l'incubation des maladies charbonneuses et à la quantité de virus nécessaire à la transmission de la maladie', Bull. Acad. imp. Méd., 1868, 33, 816-821.

13 Davalne, C., 'Études sur la contagion du charbon chez les animaux domestiques', Bull. Acad. imp. Méd., 1870, 35, 215-235.
} 


\section{Casimir Davaine: A Precursor of Pasteur}

case, Davaine was on the wrong track for if flies were the real carriers of the disease, the lesions should be external at the point of inoculation. Such lesions are very exceptional. In fact, as we know today, animal anthrax is transmitted in most cases by the ingestion of fodder contaminated by the bacteridian spores. These penetrate the digestive mucosa by means of scratches caused by prickly bits of straw or husk, etc. Transmission by insects is altogether exceptional. In spite of further research, Davaine was still far from the final solution of the aetiology of anthrax. As Straus pointed out:

Faced with these hesitations and uncertainties ... the opponents of the parasitic theory raised again their heads and found there an argument in favour of the spontaneous nature of the disease.

Those who shared this opinion went as far as to say with Pidoux, 'The disease is within us, from us, by us'.

The medical training of Davaine was an incentive to him to search for the means of destroying the bacteridia and thus to prevent the disease. As early as 1873 he had shown that anthracic blood diluted in water is no longer infectious when heated to $55^{\circ} \mathrm{C}$. for five minutes. But if the blood is dried the bacteridia retain their virulence even if heated to $100^{\circ} \mathrm{C}$. Davaine recalled at this point his previous observations on the bacterial disease in plants and those of Pasteur on the heating of wines.

Not only did Davaine try to destroy bacteridia in vitro, but he tried as well to obtain the same effect in vivo. By using anthracic guinea-pigs he succeeded in arresting the development of the malignant pustule, by applying a piece of iron heated to $51^{\circ} \mathrm{C}$. on the lesions. He did not stop there and in the same year (1873) he carried out research on the action on the bacteridia of chemicals, diluted acids, ammonia, potash, permanganate, and iodine in solution. ${ }^{14}$

Davaine went one step further. In one of his last papers to the Academy of Medicine (1880) he reconsidered the treatment of human anthrax by iodine and confirmed the 'antiseptic' action now called antibiotic of walnut leaves shown by Pomayrol in 1853.15 Davaine inoculated two guinea-pigs with an aqueous solution of anthracic blood to which powdered walnut leaves were added, and the animals were unaffected. Davaine intended to complete the above in vitro experiments by new in vivo ones which his untimely death prevented him from accomplishing.

Ten years ago (1954-56) Dr. E. Lagrange of Brussels, showed that walnut leaves have an effective antibiotic action on the anthracic bacteridia. ${ }^{16}$ Jean Rostand has pointed out the significance of this discovery as an example in the history of science where the significance of an observation made a century ago was not appreciated until recently. ${ }^{17}$

As we have already seen, Davaine separated anthrax from septicaemia. In 1872 Davaine, by repeating the work of Coze and Feltz, showed that the putrefied cow-

14 DavaIne, C., 'Recherches relatives à l'action des substances dites antiseptiques sur le virus charbonneux', C. r. Acad. Sci., 1873, 77, 821-825.

15 THéoDorIDĖ, J., 'Un précurseur de l'antibiothérapie: Louis Pomayrol (1819-1899)', Hist. Méd., No. spécial 1959, 81-86.

16 LAGRANGe, E., 'Casimir Davaine doublement précurseur', Presse méd., 1955, No. 12, 234-235.

17 Rostand, J., 'Casimir Davaine et les antibiotiques', Rev. Hist. Sci., 1957, 10, 86-87. 


\section{Jean Théodoridès}

blood inoculated into rabbits and guinea-pigs was the cause of fatal septicaemia. He inoculated a group of 25 rabbits (each of them with the blood of the preceding one) performing what is called today the passage method. At the 5th the fatal dose is one hundredth of the original blood and at the 25th it is one trillionth of a drop. Davaine concluded, 'the septicaemic virus acquires greater virulence by passing through the body of a living animal'. He also showed that, contrary to what one would expect, the more recent the putrefied blood, the more virulent it is.

Finally, Davaine thought that the virulent factor of the disease was similar to the 'putrefaction ferment' (that is to say, the butyric ferment that Pasteur had studied in 1863). In 1873 Colin (who was later to become Pasteur's opponent) criticised this work. According to him, the injection of putrid blood did not always result in septicaemia, and he asserted that the virulence of the blood was not necessarily due to the presence of pathogenic micro-organisms.

In 1877 and 1879, Davaine defined septicaemia as being 'a putrefaction which takes place in the blood of a living animal'. He believed that this disease could be produced by several 'viruses' (the term being understood in the meaning of an infectious agent). But Davaine was unable to discover the microbe responsible for this disease for which he was searching in the blood, whereas, in fact, it is to be found in the abdominal serosity. It was not until 1877 that Pasteur and Joubert isolated it and called it 'vibrion septique' (Clostridium septicum).

In conclusion, it can be said that Davaine's contribution is fundamental to the development of medical bacteriology. He did not succeed, however, in finally elucidating the exact mode of transmission of anthrax because he had not discovered the spore of bacteridia, which explains the persistence of the disease and its fresh outbreaks in a contaminated area. This decisive stage of the life-cycle of the bacteridium was revealed by Robert Koch in his famous memoir of 1876 , followed by the celebrated research of Pasteur, Roux and Chamberland (1877-1881), which was to lead to the spectacular experiment at Pouilly-le-Fort of anthrax vaccination.

Although Davaine failed in isolating the bacteridia and in cultivating them in vitro, it remains to his credit that it was he who unravelled the intricate problem of anthrax and septicaemia some fifteen years before Koch and Pasteur. His first observation of 1850 , made in collaboration with Rayer, preceded those of his illustrious successors by 25 years. It should also be remembered that his controversies with Leplat, Jaillard and particularly Colin foreshadowed Pasteur's memorable arguments with the opponents of the microbial theory of disease.

The bacteriological research work of Davaine and of Pasteur complement each other perfectly. It will be remembered that it was Pasteur's work in 1861 on butyric fermentation that inspired Davaine to compare the bacteridia to the butyric vibrios. In the same way, when Davaine was working on a bacterial disease in plants he borrowed Pasteur's idea on the heating of wines (1866). We know, on the other hand, that Pasteur, who was not a medical man, hesitated in dealing with infectious diseases in man and animal. Anthrax had been studied in detail by the physician, Davaine, whose name is mentioned 75 times in the complete works of Pasteur. In a letter addressed to Davaine in 1879, Pasteur writes: 'I pride myself for having so often followed up your own learned research.' 
Casimir Davaine: A Precursor of Pasteur

Most of Pasteur's pupils-Duclaux, Chamberland, Straus, Arloing, etc.-paid homage to Davaine.

Finally, he is one of the precursors of chemotherapy and antibiotic therapy.

For all these reasons his name, which is hardly known to the general public, should be saved from an unjustified oblivion. One of the main aims of the history of science is to see that the great, but often unknown, scientists should be awarded their rightful place. 